\title{
21. FEATURES OF GRAIN-SIZE DISTRIBUTION AND MINERAL COMPOSITION OF TURBIDITIC SEDIMENTS FROM THE MIDDLE AMERICA TRENCH OFF GUATEMALA ${ }^{1}$
}

\author{
Tsunemasa Shiki, Faculty of Science, Kyoto University, Kyoto, Japan \\ Teiji Yamasaki, Osaka University of Education, Ikeda, Osaka, Japan \\ and \\ Kunihiko Hisatomi, Faculty of Science, Kyoto University, Kyoto, Japan
}

\begin{abstract}
Features of grain-size distribution, mineral composition, and microfossils of turbiditic sediments from the Middle America Trench off Guatemala were studied using an "ultrasonic vibrator" technique and scanning electron microscope. Two kinds of trench-fill turbidites were recognized. Turbidite sediments of Site 499 were probably transported down the continental slope through a canyon. Slump-origin turbidites of Site 500 indicate a rapid increase of slope angle at the continental slope.

The presence of Quaternary, very clayey, turbidite sands offers alternate evidence on the current theory of the diagenetic origin of the clay matrix in ancient turbiditic graywacke sandstones.

Terrigenous and shallow-sea derived components in samples from Hole 495, situated $22 \mathrm{~km}$ seaward of the trench axis and about 1925 meters above it, are most probably explained by the transport of sediment suspended in a dilute density current detached from near-bottom turbidity currents.
\end{abstract}

\section{INTRODUCTION}

The Middle America Trench was recommended for drilling transects by the IPOD Active Margin Panel on the basis of past drilling experience. In high latitudes, the influx of terrigenous sediments during glaciation makes it difficult to differentiate trench deposits from ocean-basin deposits and slope deposits. Optimum conditions for a study of plate convergence would be found in an area where terrigenous sources are small, faunal diversity great, and subduction relatively rapid (von Huene, Aubouin, et al., 1980). Detailed study of sediment cores from the Middle America Trench and its surroundings should help us comprehend trench tectonism around the Pacific.

In this chapter we wish to supply some sedimentological information on turbidites and related sediments obtained on Leg 67 in the Guatemala trench in order to increase understanding of the environmental and tectonic conditions under which the sediments were deposited. We concentrate principally on information derived from grain-size distribution and mineral composition measured in connection with structures and textures of the sediments. Shiki $(1959,1961,1962)$ has obtained by such combined studies much valuable information on the process of sedimentation of the Permian turbiditic sediments in Japan. Similar combined study also affords good information on the sediments of the present Guatemala trench region.

\section{METHODS}

We analyzed about 90 samples using a new technique introduced in this study-the sieving of sediment through a metallic filter bathed in

\footnotetext{
I Aubouin, J., von Huene, R., et al., Init, Repts. DSDP, 67: Washington (U.S. Govt. Printing Office).
}

alcohol under sonic vibration. These instruments, "ultrasonic vibrator," metallic filter, and special funnel for the filter, developed by Kokusai Electronic Industrial Co., are shown in Figure 1. This method requires only a very small amount $(0.02-0.1 \mathrm{~g})$ of sample. The ultrasonic wave is radiated from a rod of the vibrator. The filter openings are $200,100,50,25,20,15,10,5$, and $2 \mu \mathrm{m}$. Grains coarser than 200 $\mu \mathrm{m}$ were sieved by the usual technique.

Using an optical microscope, we studied mineral and fossil composition of some selected size-class fractions of the sieved samples. We did not treat grains smaller than $2 \mu \mathrm{m}$ in size. Constituents and textures of some selected samples were observed by a scanning electron microscope (SEM).

\section{SITE 499}

Five holes were drilled at Site 499 on the floor of the Middle America Trench off Guatemala. Results clarified that the Trench is filled with a rather uniform upper Quaternary (slightly less than $4 \mathrm{~m} . \mathrm{y}$. old) sequence of alternating muds, and muddy and sandy turbidites with some ash layers, underlain by an abbreviated but complete oceanic section (Aubouin, von Huene, et al., 1979; von Huene, Aubouin, et al., 1980).

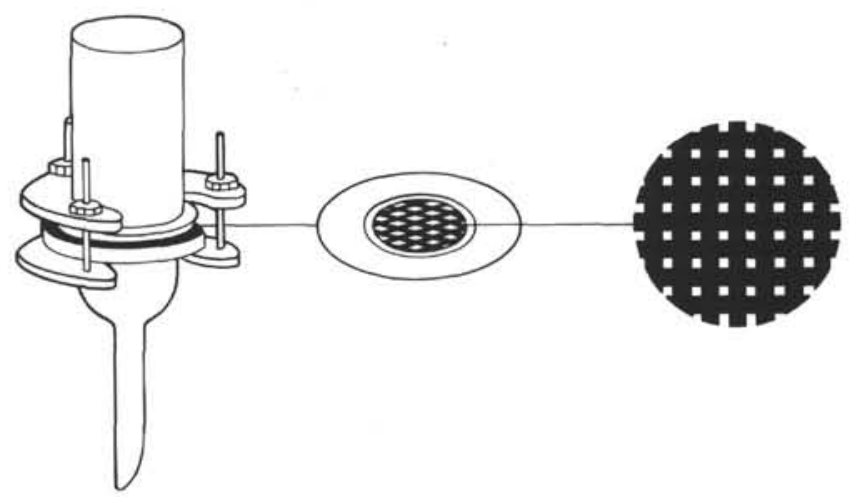

Figure 1. "Ultrasonic vibrator"' and special funnel and metalic filter (designed by Kokusai Electronic Industrial Co.). 
Limited time on board the Glomar Challenger and bad preservation of samples kept us from observing in detail sedimentary structures of the turbiditic cores. Fine structures such as fading ripples (Stow and Shanmugam, 1980), climbing ripples, and convolute laminations were not confirmed.

We analyzed for grain-size distribution about 50 samples from several graded and partly laminated sandy turbidite beds and mud beds. Selected samples of muds were studied with the scanning electron microscope.

Figure 2 shows histograms of grain-size distribution of samples from two graded beds in a Hole 499 core and the lithological features and the stratigraphical situations of the beds. Weight percentages of each class that is divided along a $\phi$ scale were recalculated on the basis of cumulative curves determined by filter-opening sizes. The histograms document a type of normal size grading in each bed-that is, not only mode but also size distribution shifts to progressively finer sizes from the bottom to the top of the bed. Such type of grading seems to belong to the "distribution grading" of Middleton (1967), which is characteristic of graded beds deposited layer by layer from relatively dilute turbidity currents.

Silty clays from the uppermost part of each bed, however, might be hemipelagic sediments, as is shown by the orientation of fossil fragments and clay flakes subparallel to the bedding planes (Fig. 3B). O'Brien et al., (1980) reported similar subparallel orientation of the flakes of hemipelagic sediments in the uppermost part of each graded bed in the Pliocene formations of the Boso Peninsula, Japan.

Sorting of sand plus silt-size grains is good in the lower part of turbidite beds and poor in the upper part. It is exceptionally good in the lowermost part of a bed in Core 7 (Sample 499-7-4, 105-107 cm). Skewness is positive in general except in a few samples. The most remarkable feature of the Figure 2 histograms is the unexpected large amount of materials finer than $2 \mu \mathrm{m}(=9$ $\phi$ ) in many samples. It exceeds $30 \%$ to $40 \%$ in some sandy samples. No samples show an obvious polymodal character on the histograms, but cumulative curves of grain sizes of some samples reveal such character in the attitude of their curves and in the breaks in their slopes (Fig. 4).

Figure 5 shows a few examples of the mineral (and microfossil) composition of sands and silts of Hole 499 sediments. In general, plagioclase, andesitic rock fragments, volcanic glass, tests of foraminifers, and some mafic minerals are major constituents of coarse fractions of Hole 499 turbidites. Black micronodules are present. Hypersthene occurs in certain samples. Pollen appears in small amounts also. Bubbled and pulledapart structures of the glass, together with the presence of oxihornblende, document subaerial or very shallow sea eruptions.

The close relation between the mineral (and microfossil) composition and grain size of the sediments found in the Permian and Triassic formations in Japan (Shiki, 1959 ) is clearly seen in the Site 499 sandy samples. Even the polymodality of the grain-size distribution relates to the variability of constituent size. For example, the ma- jor constituents of the mode around $3 \phi$ in a sample from Core 7 , Section $4,76 \mathrm{~cm}$ are terrigenous minerals, whereas the constituents of grains of $1.6 \phi$ are calcareous microfossils. Shiki (1961) has also pointed out that mineral composition changes from the base to the top of a bed in relationship to changes in grain size. Similar relationships between the mineral composition, grain size, and structure of beds are present in the case of Guatemala trench-fill turbidites.

\section{SITE 500}

Site 500 is at the base of the Middle America Trench landward slope at the juncture of the slope and the floor. Three holes were drilled at the site. The lithologic sequence at Site 500 is basically the same as at Site 499 (compare Figs. 2 and 6).

We analyzed about 30 samples of turbiditic sediments from Hole 500 for grain size and observed several samples with the SEM. Samples taken from the turbiditic beds showed normal size grading and partly parallel lamination. Many were muddy, very fine to fine sands having their mode in coarser size classes, containing medium and even, though rarely, coarse sands. Mode and size distribution in many Hole 500 beds do not shift to finer sizes, but the mode tends to decrease in height at a fixed size class from the bottom to the top of the beds (Fig. 6). No well-sorted layer was found in cores of Hole 500 . Hole 500 contains a larger percentage of $<2-\mu \mathrm{m}$ sediments than does Hole 499. Bimodal character of the size distribution of sand plus silt grains is faintly seen (Fig. 7).

Coarse-grained fractions of sandy samples are composed mainly of rock fragments, plagioclases, and volcanic glass (Fig. 8). Fractions of finer size classes contain large amounts of altered rock fragments and altered minerals. Siliceous fossil fragments are also common only in finer fractions: however, fossil content is less than that in samples from Hole 499. Paucity of calcareous fossils is a distinctive feature of Hole 500 samples. $\mathrm{K}$-feldspar is present. Volcanic glass shards of Hole 500 samples have a visicular texture similar to that of Hole 499: however, many shards of the former have a pale brownish tint and show weak birefrigence, and clayey materials (not dislodged by the sonic method) stick in the bubble holes of the shards. Volcanic rock fragments having a weathered reddish groundmass occur in Hole 500 samples and indicate eruptive activity on land or in very shallow sea. Mineral grains, glass shards, altered fragments, and calcareous fossils have a thin black oxide coating that appears on altered samples, whereas no fresh grains are coated.

In general, Hole 500 samples are markedly rich in weathered and/or altered grains. They contain a higher amount of terrigenous clayey materials and are poorer in calcareous microfossils compared to the samples from Hole 499.

\section{SITE 495}

Site 495 is on oceanic crust, $22 \mathrm{~km}$ seaward of the trench axis and about 1925 meters above it, on a ridge or hill. It is the oceanic reference for the Middle America 
Core 7

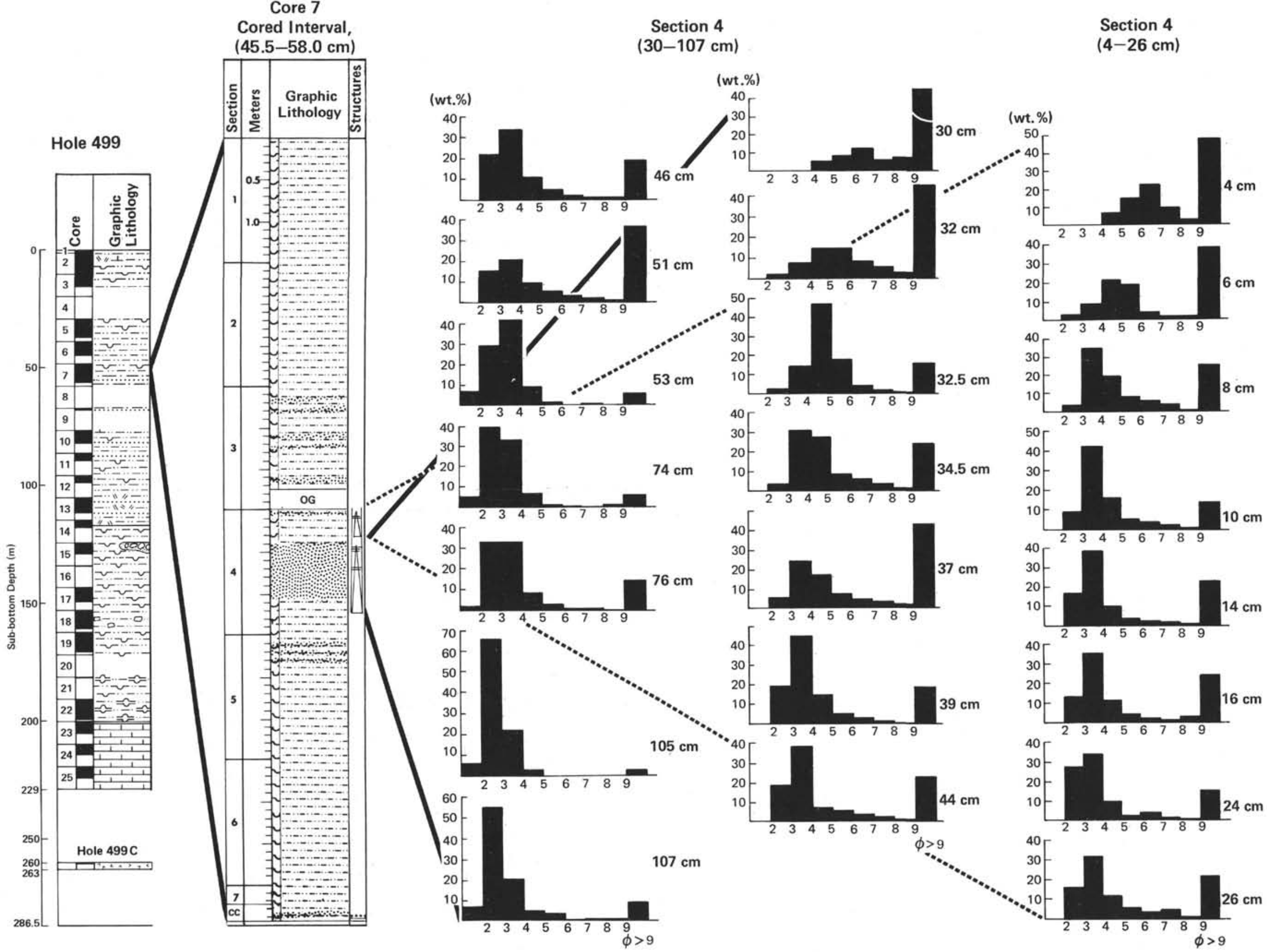

Figure 2. Histograms showing stratigraphic positions and grain-size distribution of samples from two turbidite beds of Hole 499, Core 7. (In the Graphic Lithology column, OG = wholecore organic geochemistry sample.) 

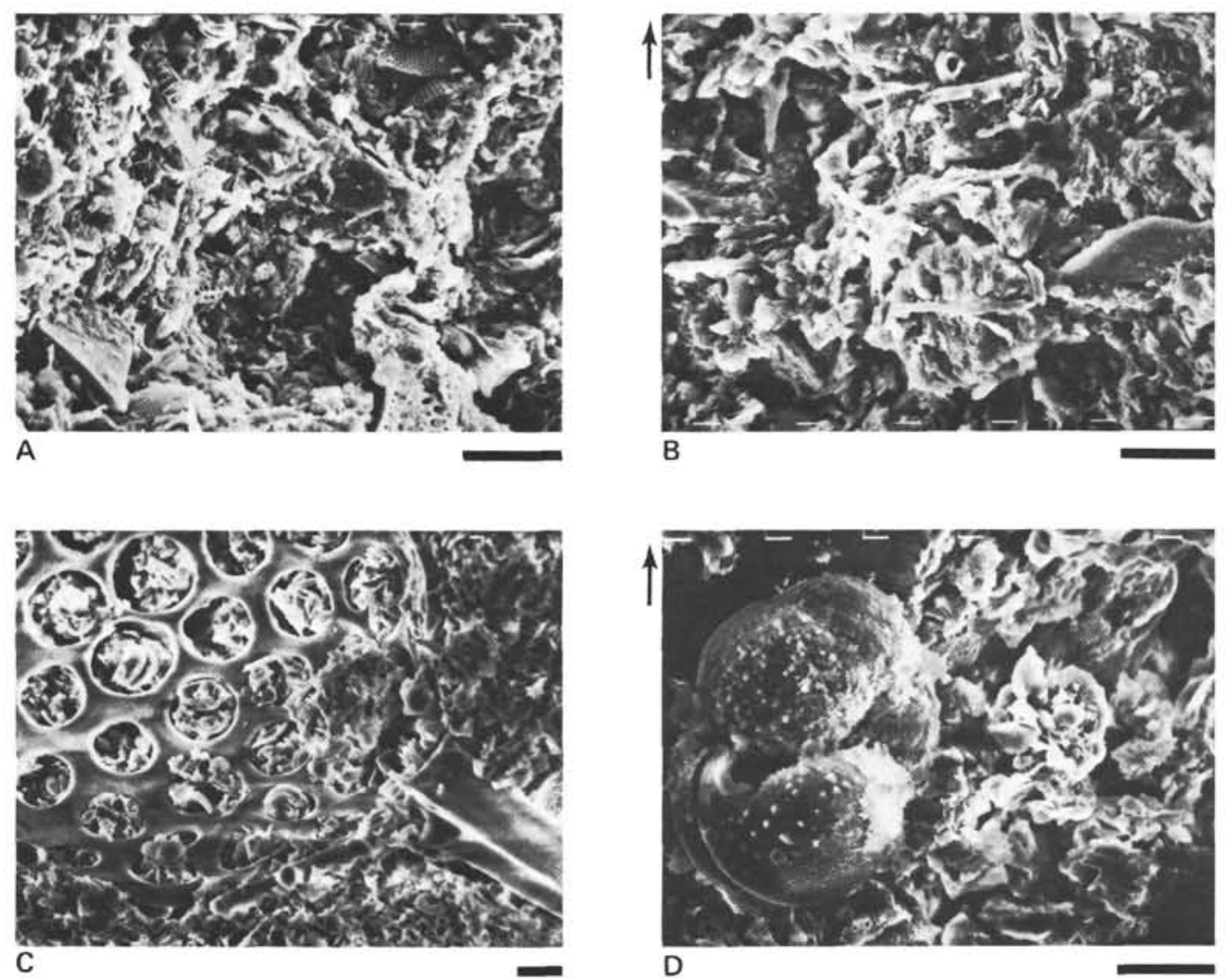

Figure 3. A. A scanning electron photomicrograph of mud. (The photograph is parallel to the bedding plane. Sample $499-7-4,30 \mathrm{~cm}$. Scale bar $=10 \mu \mathrm{m}$.) B. A scanning electron photomicrograph of mud. (The photograph is perpendicular to the bedding plane. Note the orientation of fossil fragments and clay flakes subparallel to the bedding plane. Sample $499-6-4,8 \mathrm{~cm}$. The arrow indicates the direction of the top of the bed. Scale bar $=10 \mu \mathrm{m}$.) C. A scanning electron photomicrograph of nannofossil ooze. (Parallel to the bedding plane. Sample 495-25-7, $16 \mathrm{~cm}$. Cavity of a radiolarian fossil is filled with nannofossils and fragments of fossils. Scale bar $=10 \mu \mathrm{m}$.) D. A scanning electron photomicrograph of siliceous mud. (Perpendicular to the bedding plane. Sample 495-16-7, $42 \mathrm{~cm}$. Note the clay flakes and a well-preserved foraminiferal(?) fossil. The arrow indicates the direction of the top of the bed. Scale bar $=10 \mu \mathrm{m}$.)

Trench transect off Guatemala. The lower sequence of sediment is typical of oceanic area and has a hemipelagic cover (Fig. 9). Shallow-water benthic foraminifers, pollen, plant fragments, and some terrigenous mineral grains such as quartz, feldspar, detrital clay minerals, and land-derived volcanic debris have been found from the Quaternary hemipelagic sediments.

The size distribution of the hemipelagic (or, hemiterrigenous) sediment samples of Hole 495 resembles that of samples from the uppermost part of the individual beds of the trench-fill sediments (Fig. 9). Micronodules and fragments of siliceous fossils such as diatoms and radiolarians are abundant in fine to very fine silt fractions, although no peculiar minerals or fossils are concentrated in the modal class fraction of the samples (Fig. 10). Well-preserved radiolarians are rich in very coarse silt fractions. (The siliceous fossils are the most important elements of the upper Miocene pelagic sediments). Terrigenous grains (rock fragments, plagioclases, and volcanic glasses) are abundant in the coarse silts and very fine sands. No K-feldspar grain was detected in Hole 495 cores. Rounded fragments of calcareous benthic foraminifers, very fine sands in size, are rare constituents of the samples. As a whole, the hemipelagic sediments of Hole 495 resemble those of Hole 499 sediments rather than Hole 500 sediments.

\section{DISCUSSION}

\section{Generation of Turbidites from the Trench Slope and from Slumps on the Trench Slope}

Notable differences exist between sedimentary features of samples from Site 500 and Site 499. These differences suggest a different mechanism of transportation and deposition. "Nondistribution" type size grading, lesser sorting, and larger amounts of clay in the Site 500 samples suggest transportation in a current of higher clay content and higher density. Alteration of rocks and minerals including glass shards, oxide coat ing, and clay in bubble holes of shards indicate that these grains had been deposited first and had undergone diagenetic alteration, and had then been reworked and redeposited at their present location on the trench floor. Noncoated and nonaltered fresh grains also occur in large amounts in the Site 500 samples. That is, clay-rich, altered sediments and fresh sediments are highly mixed together at this site. Slumping and subsequent muddy turbidity flow is suggested as the mechanism producing 

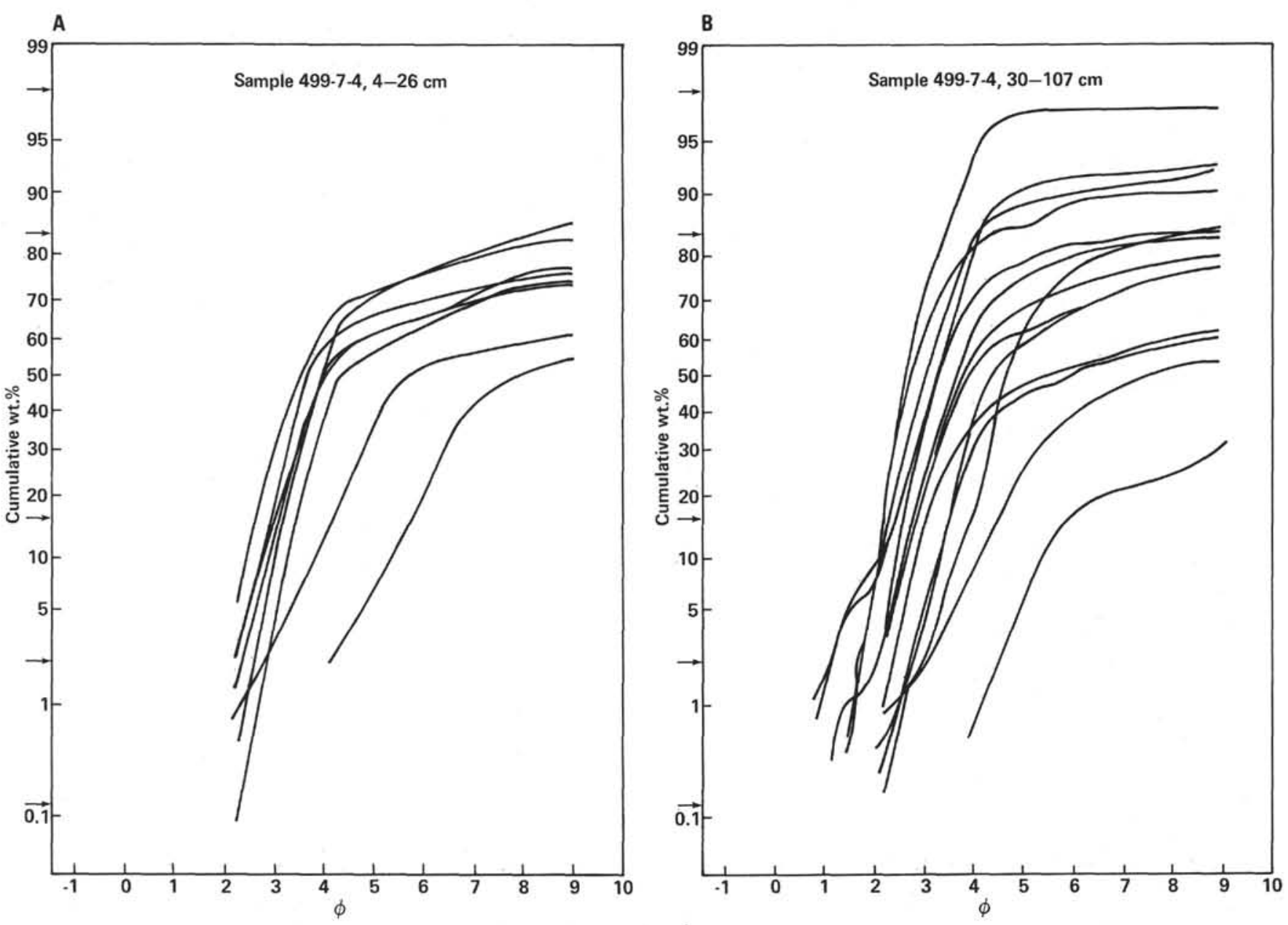

Figure 4. A and B. Cumulative curves of grain sizes of some samples from Hole 499, Core 7. (Breaks in slope and undulation of the curves indicate the polymodal character of the size distribution.)

such mixing and codeposition of sediments of different origin and, most probably, of different age.

On the contrary, "distribution grading" and better sorting of Hole 499 beds show deposition from a relatively dilute turbidity current. These features of size grading and the limited amount of altered materials together with a relative abundance of calcareous fossils and the occurrence of pollen in Hole 499 samples reveal that sediments from a shallow-water environment were directly supplied by turbidity currents to the trench floor, probably through canyon (Fig. 11).

In general, turbidite accumulation in a trench may reflect not only the appearance of a trench basin and its slopes but also an increased supply of sediments related to fluctuations of sea level between glacial and interglacial stages. But slump-origin turbidites of Site 500 safely indicate rapid increase of angle of the continental slope, and most probably reveal fall of the trench bottom that caused the slump of the slope sediments.

\section{Clay Content and Graywacke Problem}

Both grain-size distribution and clay content are related to the process of transportation, deposition, and postdepositional change of the sediments. Cummins (1962) has emphasized that there is a direct correlation between the percent of clay matrix and the age of graywacke. He argued that most of the matrix material in graywacke sandstones of turbiditic formations results from the diagenetic breakdown of unstable sand grains. Pettijohn et al. (1972) suggested that the modern equivalents of the matrix-rich ancient graywackes are the immature sands with high amounts of argillaceous and/or volcanic rock fragments that were deposited in basins where they are subjected to deep burial and low-grade metamorphism or high-grade diagenesis.

Diagenetic origin of some graywacke matrix is undeniable, as stated by Brenchley (1969), Buller and McManus (1972), Galloway (1974), Wilson and Pittman (1977), and others. But we think the problem remains unsolved. A few instances of Recent wacke-type (muddy) deep-sea sands have been reported (Hollister and Heezen, 1964; Shike, 1972; Moore, 1974). The finding of very clay-rich turbidite sands in the Guatemala trench region offers new information on the "graywacke problem" and a reference for the consideration of paleoenvironment of turbidite deposition in the geological past.

\section{Transport across the Trench}

As mentioned earlier, terrigenous and shallow-waterderived components in the Hole 495 samples were one 

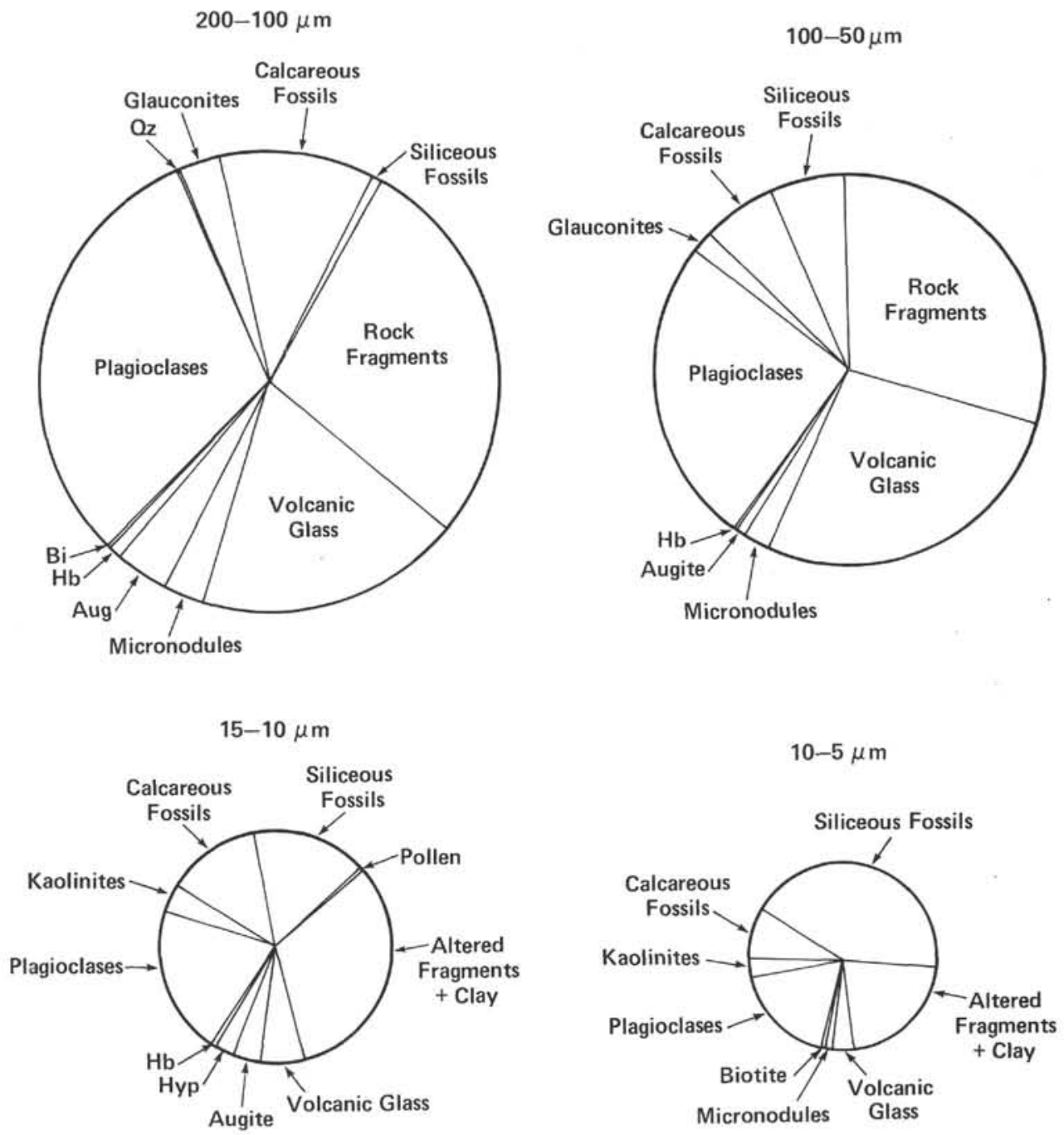

Figure 5. Mineral and microfossil composition of grains in some selected size classes of a sample from Hole 499. (Zeolites are included in the field of "Altered Fragments + Clay.")

of the interesting finds of the Leg 67 drillings. Transport of these components by bottom turbidity current across the deep trench floor to the site seems almost impossible. In the northwestern Atlantic, the near-bottom turbid layer in the deep ocean (nepheloid layer; Ewing and Thorndike, 1965) attains an average thickness of about 1000 meters (Eittreim and Ewing, 1972). But Site 495 is situated about 1925 meters higher than the trench floor. Transport by suspension in a layer detached from the near-bottom turbid current layer, as stated by Drake et al. (1972) and Pierce (1976), seems the most probable explanation of the presence of the terrigenous grains and shallow-water fossil fragments at Site 495 (Fig. 12).

In the samples we examined, the compositional character of Site 495 sediments resembles more that of Site 499 sediments than that of Site 500 sediments. This fact suggests that the layer was detached from the turbidity current, which came down through a canyon on the continental slope. However, the samples we studied are small in number. At present we cannot deny the pres- ence of some materials transported by suspension in layers detached from slump-origin turbidity currents.

\section{ACKNOWLEDGMENTS}

We are very grateful to all the Leg 67 cruise members including the scientists and technicians who gave to the first author considerable help and assistance. We are indebted to Prof. Nasu, Dr. Mizuno, Prof. Okada, Dr. Honza, Mr. Fujioka, and others who provided much useful advice. We also would like to thank Prof. O'Brien and Prof. Imoto for critically and helpfully reviewing the paper.

\section{REFERENCES}

Aubouin, J., von Huene, R. E., et al., 1979. Preniers resultats des forages profonds dans le Pacifique au Niveau de la fosse du Guatemala (fosse ci Amerique Centrale) (Leg 67 du Deep Sea Drilling Project: mai-juin 1979). C. R. Acad. Sci. Ser. D, t. 289, pp. 1215-1220.

Brenchley, P. J., 1969. Origin of matrix in Ordovician graywackes, Berwyn Hills, North Wales. J. Sediment. Petrol., 39:1297-1301.

Buller, A. T., and McManus, J., 1972. Mode of turbidite deposition deduced from grain-size analyses. Geol. Mag., 109:491-500.

Cummins, W. A., 1962. The greywacke problem. Liverpool Manchester Geol. J., 3:51-72. 
Drake, D. E., Kolpak, R. L., and Fischer, P. J., 1972. Sediment transport on the Santa Barbara-Oxnard shelf, Santa Barbara channel, California. In Swift, D. J. P., Duane, D. B., and Pilkey, O. H. (Eds.), Self Sediment Transport: Dowden (Hutchinson \& Ross), pp. 307-331.

Eittreim, S., and Ewing, M., 1972. Suspended particulate matter in the deep waters of the North American Basin. In Gordon, A. L. (Ed.), Studies in Physical Oceanography: New York (Gordon \& Breach), pp. 123-167.

Ewing, M., and Thorndike, E. M., 1965. Suspended matter in deep ocean water. Science, 147:1291-1294.

Galloway, W. E., 1974. Deposition and diagenetic alteration of sandstone in northeast Pacific arc related basins: implications for graywacke genesis. Bull. Geol. Soc. Am., 85:379-390.

Hollister, C. D., and Heezen, B. C., 1964. Modern greywacke-type sands. Science, 146:1573-1574.

Middleton, G. V., 1967. Experiments on density and turbidity currents, III. Deposition of sediment. Can. J. Sci., 4:475-505.

Moore, J. C., 1974. Turbidites and terrigenous muds, DSDP Leg 25. In Simpson, E. S. W., Schlich, R., et al., Init, Rept. DSDP, 25: Washington (U.S. Govt. Printing Office), 441-479.

O'Brien, N. R., Nakazawa, K., and Tokuhashi, S., 1980. Use of clay fabric to distinguish turbidite and hemi-pelagic siltstones and silts. Sedimentology, 27:47-61.

Pettijohn, F. J., Potter, P. E., and Siever, R., 1972. Sand and Sandstone: Berlin, Heidelberg, New York (Springer-Verlag), pp. 206-211.
Pierce, J. W., 1976. Suspended sediment transport at the shelf break and over the outer margin. In Stanley, D. J., and Swift, D. J. P. (Eds.), Marine Sediment Transport and Environmental Management: New York (John Wiley \& Sons), pp. 437-457.

Shiki, T., 1959. Studies on sandstones in the Maizuru Zone, Southwest Japan. 1. Importance of some relations between mineral composition and grain size. Mem. Fac. Sci. Kyoto Univ., Ser. B Geol. Mineral., 25:239-246.

1961. Studies on sandstones in the Maizuru Zone, Southwest Japan. II. Graded bedding and mineral composition of sandstones of the Maizuru group. Mem. Fac. Sci. Kyoto Univ. Ser. B Geol. Mineral., 27:293-308.

1962. Studies on sandstones in the Maizuru Zone, Southwest Japan. III. Greywacke and arkose sandstones in and out of the Maizuru Zone. Mem. Fac. Sci. Kyoto Univ., Ser. B Geol. Mineral., 29:291-324.

1972. Mud content of sandy sediments of turbidite. J. Mar. Geol., 8:46-54. (In Japanese with English abstract)

Stow, D. A. V., and Shanmugam, G., 1980. Sequence of structures in fine-grained turbidites: comparison of recent deep-sea and ancient flysch sediments. Sed. Geol., 25:23-42.

von Huene, R., Aubouin, J., et al., 1980. Leg 67: the Deep Sea Drilling Project Mid-America Trench transect of Guatemala. Bull. Geol. Soc. Am., Pt. 1, 91:421-432.

Wilson, M. D., and Pittman, E. D., 1977. Authigenic clays in sandstones: recognition and influence on reservoir properties and palaeoenvironmental analysis. J. Sed. Petrol., 47:3-31. 


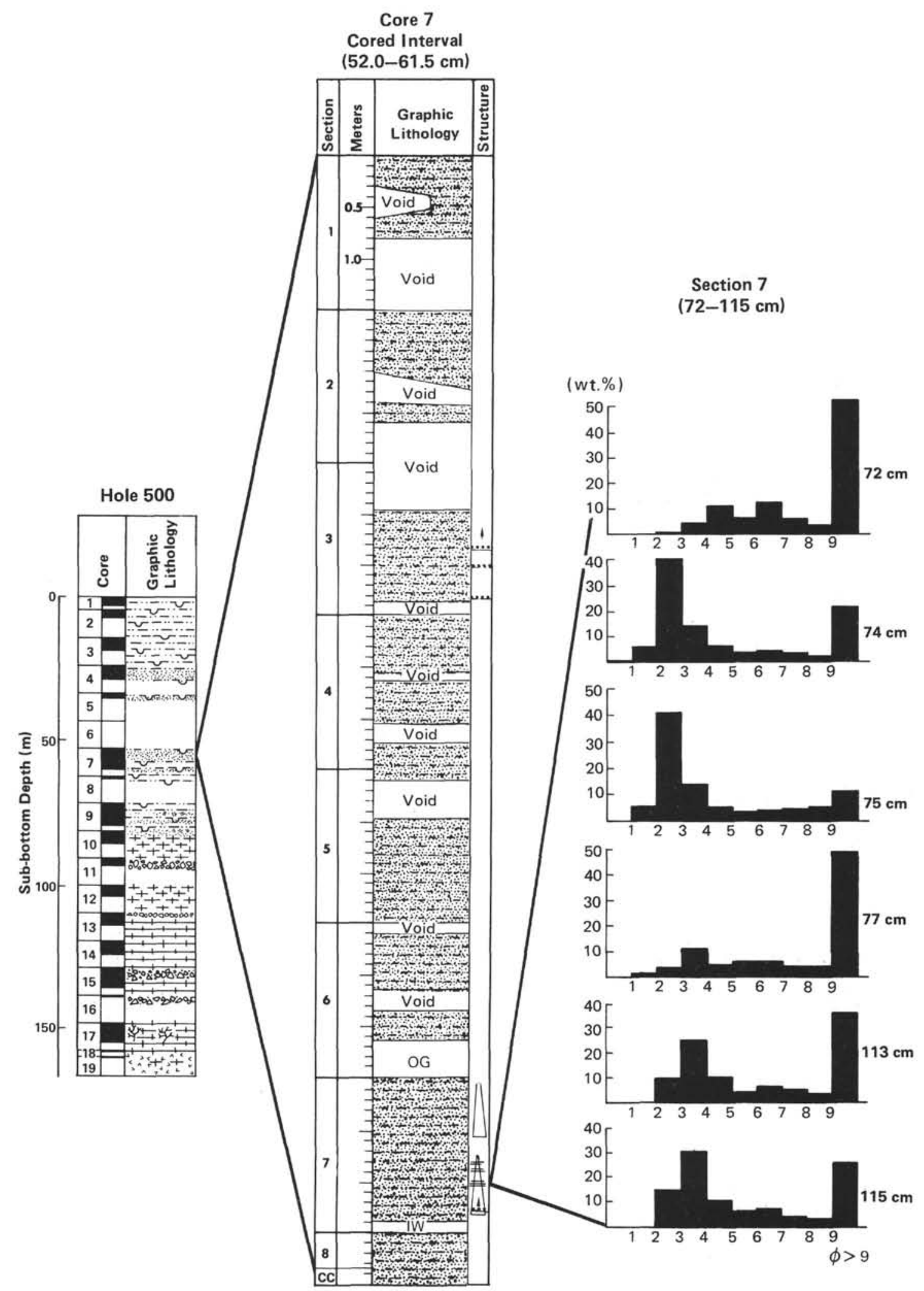

Figure 6. Histograms showing the stratigraphic positions and grain-size distribution of samples from two turbidite beds of Hole 500, Core 7. (In the Graphic Lithology column, IW = interstitial water sample; $\mathrm{OG}=$ organic geochemistry sample.) 


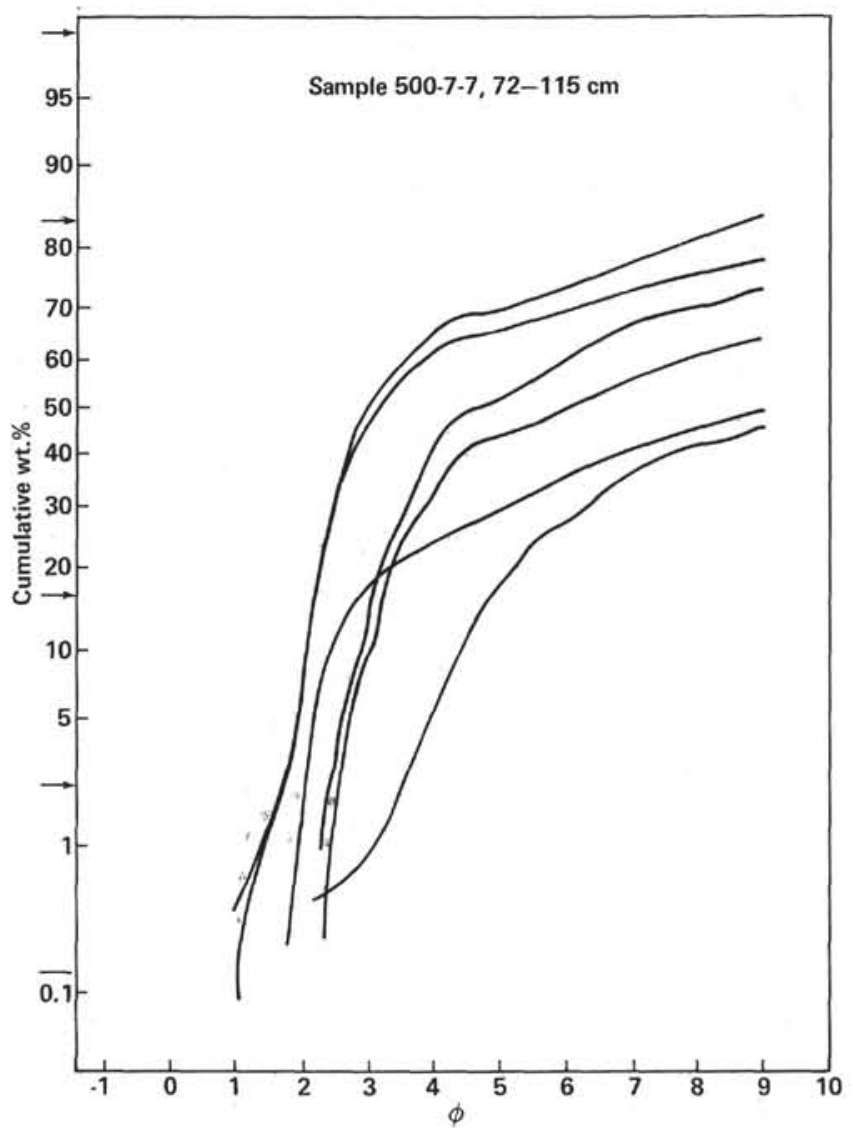

Figure 7. Cumulative curves of grain sizes of sample from Hole 500, Core 7. (Breaks in slope and undulation show the polymodal character of the size distribution.) 
Sample $500-7-7,75 \mathrm{~cm}$
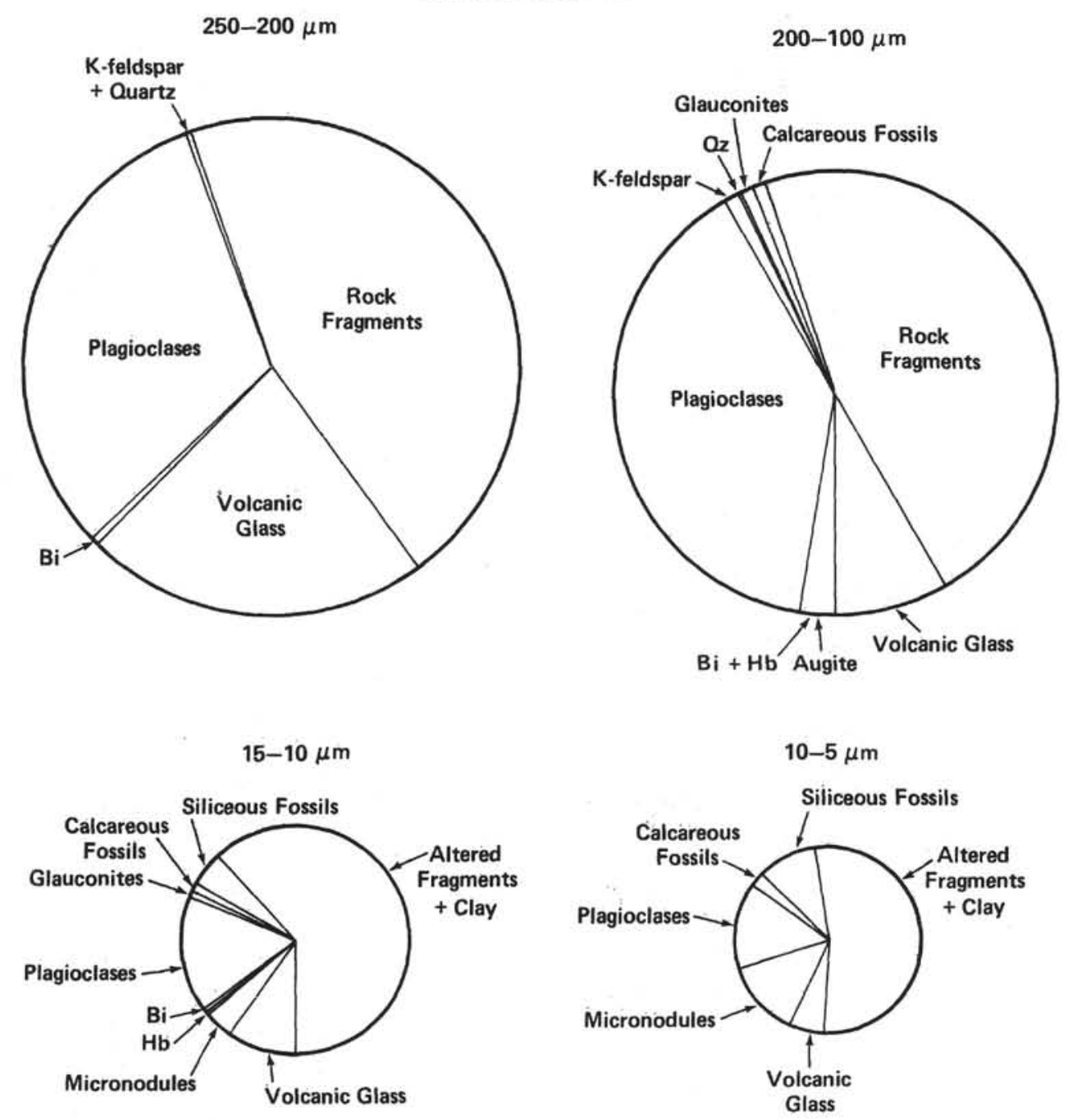

Figure 8. Mineral and microfossil composition of grains in some selected size classes of a sample from Hole 500. (Zeolites are included in the field of "Altered Fragments + Clay.") 


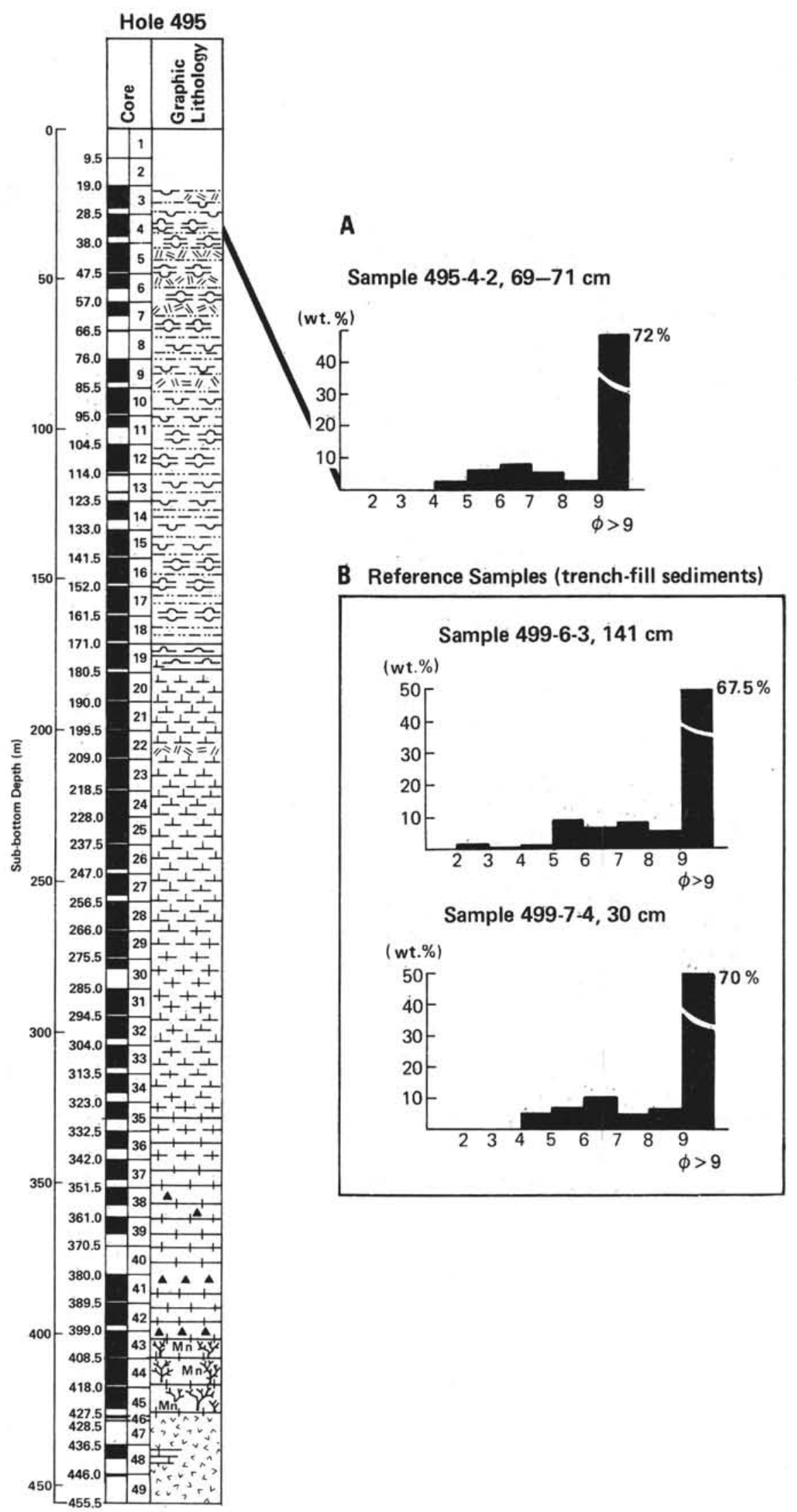

Figure 9. Histogram showing grain-size distribution of A., a sample of the hemipelagic mud of Hole 495, Core 4, and B., two reference histograms of Hole 499 trench-fill muddy sediments. 
$100-50 \mu \mathrm{m}$

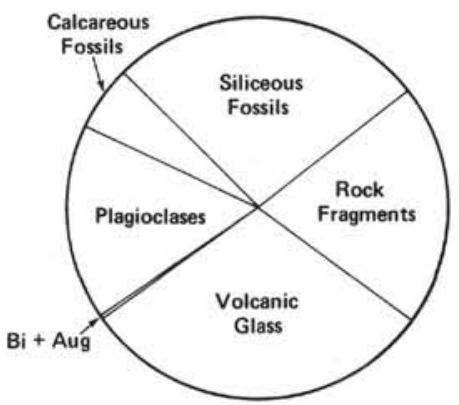

$15-10 \mu \mathrm{m}$

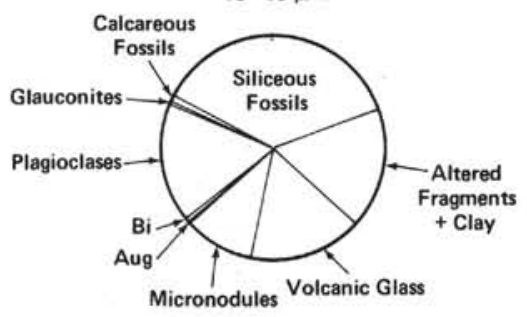

$50-25 \mu \mathrm{m}$

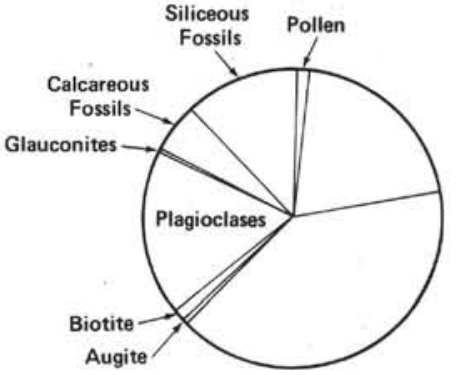

$10-5 \mu \mathrm{m}$

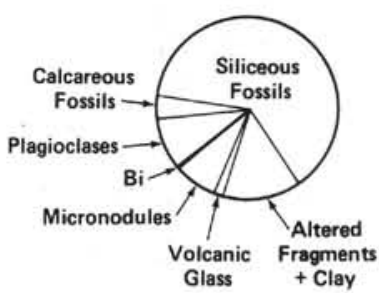

Figure 10. Mineral and microfossil composition of grains in some selected size classes of a sample of hemipelagic mud of Hole 495. (Zeolites are included in the field of "Altered Fragments + Clay.")

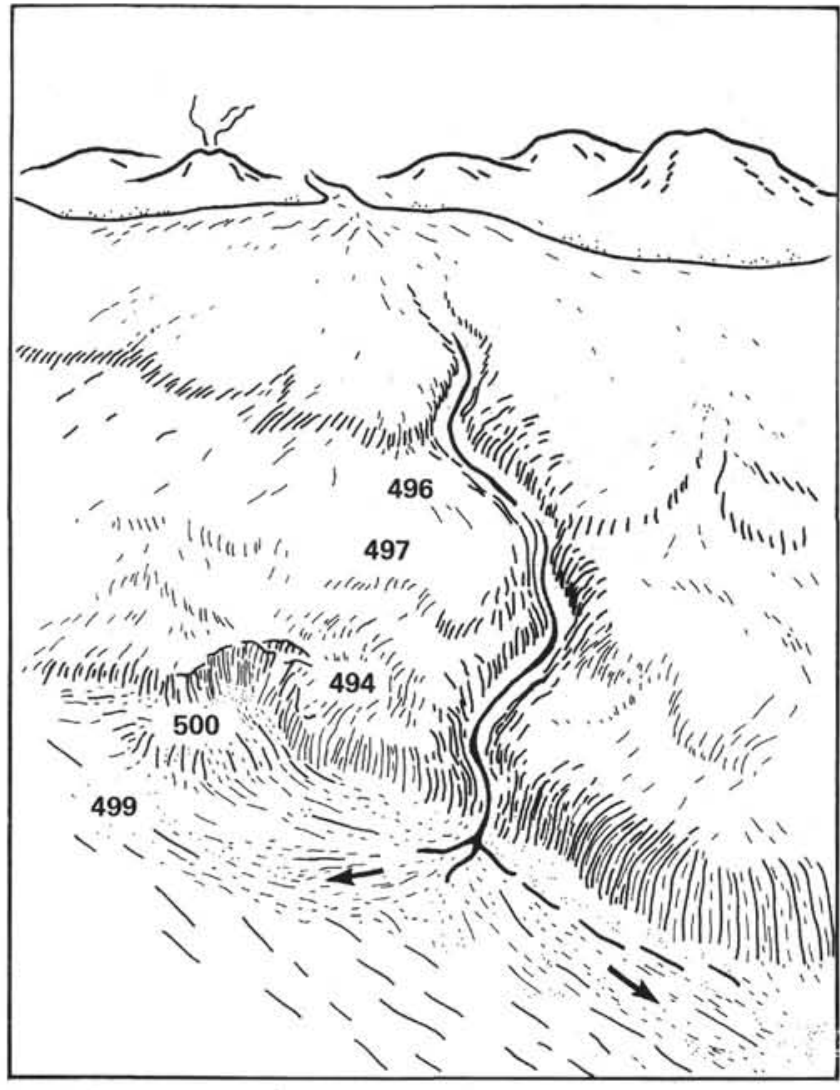

Figure 11. Schematic illustration of two different settings of turbidites in the Trench floor at Hole 499 and Hole 500.

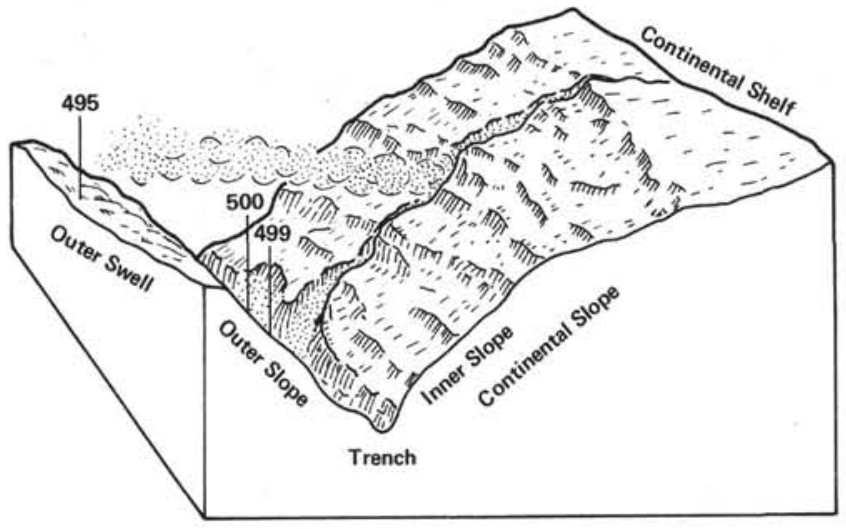

Figure 12. Schematic illustration of the transportation of terrigenously derived material to Site 495 across the Trench. 